保健物理, 26, 355 360（1991）

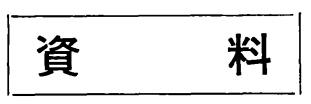

\title{
無トリチウム水を製造するための電気分解-低温酸化を 組み合わせた水製造装置の改良
}

\author{
木村捷二郎*1，宮村知宇*1，松並忠男 $* 2$
}

\author{
(1991 年 1 月 24 日受理) \\ (1991 年 8 月 5 日再受理)

\begin{abstract}
Improvement of a Synthesis Apparatus Composed of Electrolysis and Low Temperature Oxidation for Preparation of Tritium-Free Water
\end{abstract}

Syojiro KImURA, ${ }^{* 1}$ Tomotaka MiYamURA*1 and Tadao MatSUnAmI*2

An experimental investigation was carried out on the improvement of a preparation system of tritiumfree water, which is used as "back-ground water" in the determination of tritium with the liquid scintillation method, for environmental monitoring.

The fundamental consideration was based on the recombination of hydrogen gas reduced tritium content and oxygen gas in laboratory conditions. An assembly for this system was made up of two units, an electrolytic degradation unit for the generation of $\mathrm{H}_{2}$ gas, and a circulation unit of $\mathrm{N}_{2}$ as carrier gas connected with a catalyst column and a cold trap for recombination to $\mathrm{H}_{2} \mathrm{O}$. This apparatus was entirely made of glass, and designed as closed system. As operating conditions, the electric current, a circulation rate of $\mathrm{N}_{2}$ gas and a catalyst column temperature were $12 \mathrm{~A}, 2.4 \mathrm{l} / \mathrm{min}$ and $150^{\circ} \mathrm{C}$, respectively.

This system has proven to be suitable for preparation of tritium-free water, under the safe and sure condition. Three days are necessary to obtain $40 \mathrm{ml}$ of water.

KEY WORDS : synthesis apparatus, tritium-free water, tritium monitoring, back-ground water, reduced tritium content, electrolysis, low temperature oxidation

\section{I は じめに}

液体シンチレーション計数法を用いて環境水など極低 レベル濃度のトリチウムを精度よく測定するには，でき るだけ自然計数值の小さくなる条件で測定することが必 要である。そのためには計数効率のよい計測機器のみな

*1 大阪薬科大学 ; 松原市河合 2-10-65 (T580)

Osaka University of Pharmaceutical Science ; 210-65, Kawai, Matsubara 580.

*2 大阪府立大学附属研究所; 堺市新家町 174-16 (₹593)

Research Institute for Advanced Science and Technology, University of Osaka Prefecture ; 17416, Sinke-cho, Sakai 593.
らず，含有トリチウム濃度が無視できる濃度レベルの試 料水（以下, $\mathrm{BG}$ 水) を必要とする。

自然界に拈けるトリチウム量は, 人工的な放出量がご くわずかである場合，宇宙線と大気中原子との核反応に よって生じる割合と自己の壊変速度との間に拉いて平衡 状態に達するので，ほぼ一定の值である。たとえば，核 実験が開始される以前に打ける地表面での水中平均濃度 は約 $0.74 \mathrm{~Bq} / l$ であった ${ }^{1,2)}$ 。ただし，温度躍層より深 い海底や地下水のように水の循環速度の遅い場では, 上 記の核反応による供給量が少ないため, 平衡濃度として の値はより低い3。 手しらる BG 水として深海水や地下水が用いられてき 
た4)。しかし，深海水の入手は容易でないこと，さらに 近年, われわれが比較的容易に入手できる地下水には, 核実験によって環境中に放出され雨水とともに浸透した トリチウムが滞留残存し, 濃度として地表水より高い場 合もある3゙。また, 石油や天然ガスも上記のトリチウム 供給量の少ない試料であり，それらを燃焼して水分を回 収する試みや装置の開発が行われている5,6)。

一方，必要なときに，比較的入手しやすい試料から実 験室的規模の操作によって BG 水を製造することを目的 として, 森嶋らは電気分解 (以下, 電解) 法による同位 体分離を利用して無トリチウム水の製造を試み, その可 能性を報告している7)。しかし，安全性の面において未 解決であり，実用化された装置は得られていない。著者 らは, この方法をさらに発展させるため, 電解法と触媒 カラムを組み合わせた低温酸化による製造システムの試 作を試み，安全に，また比較的容易に製造できる見通し がついたので報告する。

\section{II 電気分解による軽水素とトリチウムの分離}

HTO としてトリチウムを含む水を電気分解すると, 軽水である $\mathrm{H}_{2} \mathrm{O}$ から先に水素と酸素に分解される。こ の際, トリチウムの濃縮効果は試料水中のトリチウムと プロチウム数の変化の比例係数（濃縮係数 $\beta$ ) の值とし て, 次式のように示される。

$$
\Delta H / H=\beta(\Delta T / T)
$$

両辺を積分し， $t=0$ に打ける両原子の原子数をそれ ぞれ $T_{0}$ および $H_{0}$ とすると,

$$
H / H_{0}=\left(T / T_{0}\right)^{\beta}
$$

濃縮前後の試料の液量比 $V / V_{0}$ はプロチウム原子数の 比 $H / H_{0}$ とほぼ等しく, さらに, 試料中のトリチウムの 濃度を $C$ と $C_{0}$ で表すと,

$$
\begin{aligned}
V / V_{0} & \fallingdotseq\left(T / T_{0}\right)^{\beta} \\
& =\left(C V / C_{0} V_{0}\right)^{\beta}
\end{aligned}
$$

となり,これから，

$$
\ln \left(C / C_{0}\right)=(1-\beta) \beta^{-1} \ln \left(V / V_{0}\right)
$$

となる。一般に, 害験的に求められるみかけの $\beta$ の值 は, 濃縮操作中に打ける試料水の同伴飛沫や蒸発による 損失により，真の $\beta$ の值より小さい值として得られる。 濃縮セルの構造や容量, さらに電極材料の違いによって 差はあるが，最近報告されている比較的高性能のセルで の $\beta$ の值は 20 前後 ${ }^{8)}$ である。現在,この原理を利用し たトリチウム濃縮が極低濃度試料水のトリウムを測定す るための前処理に利用されている。

これを逆に考えると，電解によって発生する水素がス 中のトリチウム濃度は試料原水より低いことになる。
ここで, 電解された水素ガスが全量, 水として回収さ れると仮定し, 回収水中のトリチウム濃度を $C_{\mathrm{T}}$ とする と

$$
C_{0} V_{0}=C_{\mathrm{T}}\left(V_{0}-V\right)+C V
$$

であるので,

$$
\frac{C_{\mathrm{T}}\left(V_{0}-V\right)}{C_{0} V_{0}}+\frac{C V}{C_{0} V_{0}}=1
$$

一方，七ル内に保持されているトリチウムの割合は (3) 式から

$$
C V / C_{0} V_{0}=\left(V / V_{0}\right)^{1 / \beta}
$$

であるので，これ(6)を式に代入して，

$$
\begin{aligned}
& C_{\mathrm{T}} / C_{0} \\
& \quad=\left[1-\left(V / V_{0}\right)^{1 / \mathrm{j}}\right] /\left[1-\left(V / V_{0}\right)\right]
\end{aligned}
$$

となり, 試料水の液量比 $V / V_{0}$ の時系列変化を知ること により， $C_{\mathrm{T}} / C_{0}$ が算出される。

さらに, 森嶋らは, 電解の初期段階または電解による 試料水の減少分を補給しながらセル内の容積を一定にす ることにより,

$$
C_{\mathrm{T}} / C_{0} \fallingdotseq 1 / \beta
$$

と近似できるとし，実験的に BG 水の製造を試みた。

具体的方法として, $28^{\circ} \mathrm{C}$ の冷却条件下の電解によって 発生した水素と酸素ガスを約 $700^{\circ} \mathrm{C}$ に加熱した粒経 10 〜24 メッシの Hopcalite（二酸化マンガン十酸化銅） 充填力ラムに導いて水に戻し, 初期の試料水量 $280 \mathrm{ml}$ から $85 \mathrm{ml}$ を電解したが, 推算值の半分の濃度減少効果 しか得られないこと，および「操作中の爆発リスクに注 意が必要である」と報告している7。

著者らは，これまで，環境試料水のトリチウム濃度を 测定するための前処理用に鉄およびニッケル板を組み合 わせた多重電極を挿入した小容量のガラス製電解セルを 設計試作し，濃縮特性のよいセルを開発できたので9), 本稿では，このセルを低トリチウム水製造システムのた めの低トリチウムガス発生系に利用することを試みた。

\section{III 低トリチウム水製造システムの構成}

\section{1. 低トリチウムガスの発生系}

著者らの開発したトリチウム濃縮用の小型電解セルを Fig. 1 に示す。電極は, 陽極としてニッケル板 3 枚と陰 極として鉄板 2 枚を対極になるように組み合わせた多重 電極であり，七ルの下部に挿入して直流電源に接続す る。電解操作中, 電極近傍における発熱に対処するた め, 七ルを低温恒温槽内に懸吊して冷却する。発生した 水素と酸素ガスはシリコン製のキャップの中央のガラス 管から排出される。電解される試料水の割合はファラデ 一定数と電流量から算出されるので, 七ル内に残る試料 


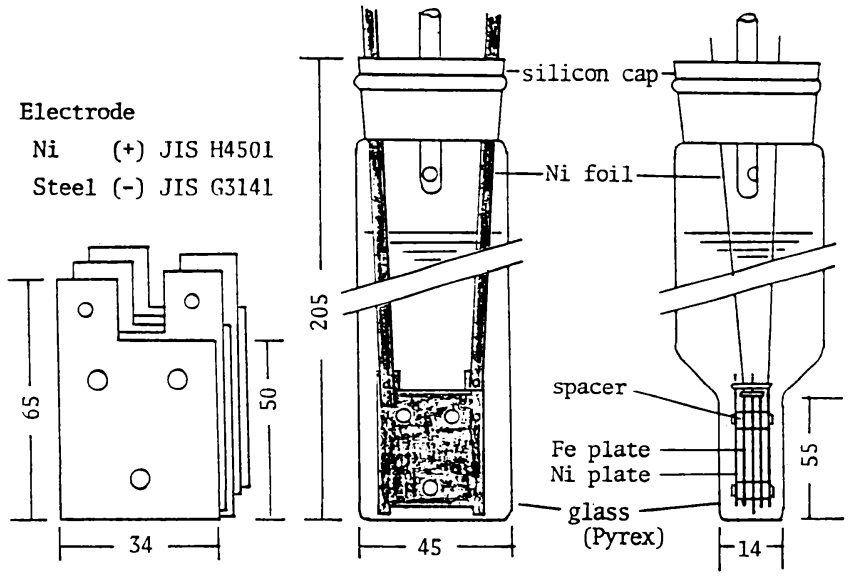

Fig. 1 Construction of multi-plate electrode and cell.

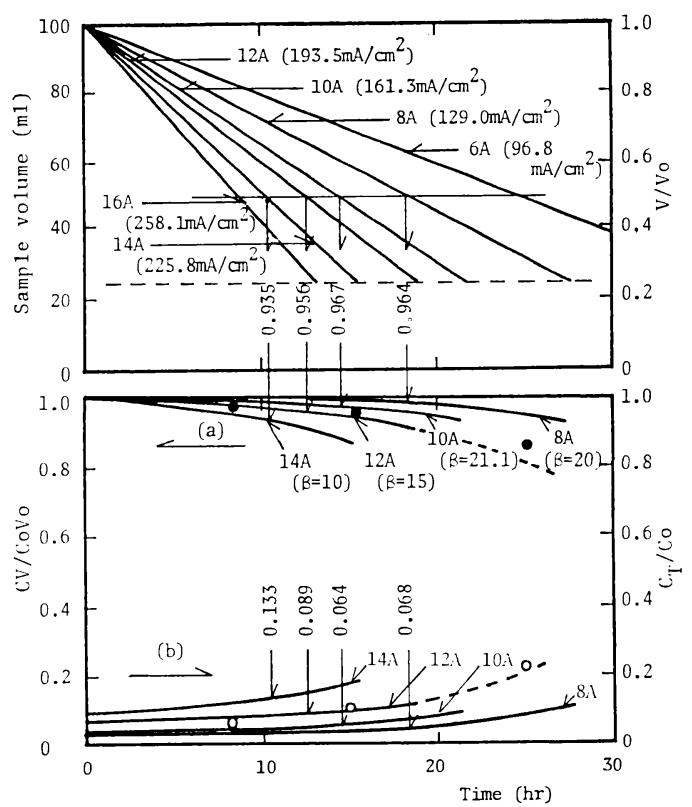

Fig. 2 Time serial correlations of residual ratio of sample water, and holding ratio of tritium in cell and tritium concentration ratio of removed water to $\mathrm{H}_{2} \mathrm{O}$.

水の割合 $V / V_{0}$ を時間との関係として表すと Fig. 2 の 上図に示すようになる。ここで，図中のカッコ内の值は 電極の単位有効面積あたりの電流值 (電流密度) である。 点線のレベルにまで試料水が電解されると, 電極が露出 し，これより以下では電極の有効面積が減少する。

一方, Fig. 1 に示した電解セルを用いて, 電流量 8 $14 \mathrm{~A}$ の条件で電解することによってトりチウムのみか けの分離係数 $\beta$ は, Table 1 に示寸値として得られてい
Table 1 Separation factors of tritium under current condition from $8 \mathrm{~A}$ to $12 \mathrm{~A}$.

\begin{tabular}{rc}
\hline Current & Separation factor $(\beta)$ \\
\hline $8 \mathrm{~A}$ & 20.0 \\
$10 \mathrm{~A}$ & 21.1 \\
$12 \mathrm{~A}$ & 15.0 \\
$14 \mathrm{~A}$ & 10.0 \\
\hline
\end{tabular}

る10)。これらの $\beta$ 值を用いてセル中に保持されるトリチ ウムの割合 $C V / C_{0} V_{0}$ を( 7$)$ 式から求めると, Fig. 2 の 下図の(a)のようになる。さらに, トリチウムの濃度減少 比 $C_{\mathrm{T}} / C_{0}$ についても (8) 式から算出すると, 同図の $(\mathrm{b})$ となる。また, 参考のために, 電流量 $12 \mathrm{~A}$, 恒温水槽 の温度 $5^{\circ} \mathrm{C}$ の条件での実測データをいおよび○の記号で 示す。その結果, $C V / C_{0} V_{0}$ および $C_{\mathrm{T}} / C_{0}$ とも計算とよ く一致している。

これらの時系列変化からわかるよらに，七ル内に保持 されるトリチウムの割合 $C V / C_{0} V_{0}$ は電流条件および $\beta$ 值に左右されるが，電解が進むとともに経時的低くな る。しかし，たとえば，七儿内の試料水が $50 \%$ 電解さ れた時点,つまり， $V / V_{0}=0.5$ でのトリチウムの保持 率は, 電流量 $8 \mathrm{~A}, 10 \mathrm{~A}, 12 \mathrm{~A}$ および $14 \mathrm{~A}$ の条件で は，それぞれ，0.964，0.967，0.956 および 0.935 であ り,さらに, 回収される試料水の相対トリチウム濃度 $C_{\mathrm{T}} / C_{0}$ は，それぞれ，0.068，0.064，0.089 および 0.133 である。

参考のため, 先の $(9)$ 式に上記の濃縮係数 $\beta$ を代入す ると,

$\left(C_{\mathrm{T}} / C_{0}\right)_{\varepsilon \mathrm{A}} \fallingdotseq 1 / 20=0.050$ 
$\left(C_{\mathrm{T}} / C_{0}\right)_{10 \mathrm{~A}} \fallingdotseq 1 / 21.1=0.047$

$\left(C_{\mathrm{T}} / C_{0}\right)_{12 \mathrm{~A}} \fallingdotseq 1 / 15=0.067$

$\left(C_{\mathrm{T}} / C_{0}\right)_{14 \mathrm{~A}} \fallingdotseq 1 / 10=0.100$

となり，いずれの電解電流条件においても上記の值より 少し小さいが，大きな差ではない。

以上のことから, 水の容積が $1 / 2$ になるまで減容電解 する過程で排出される水素ガスから， ${ }^{3} \mathrm{H}$ 濃度が原水の 1/10 以下の水を合成できることが理論的に明らかとな った。

\section{2. 水素ガスの酸化と回収システム}

トリチウム含有量の低い水素ガスを効率よく安全に酸

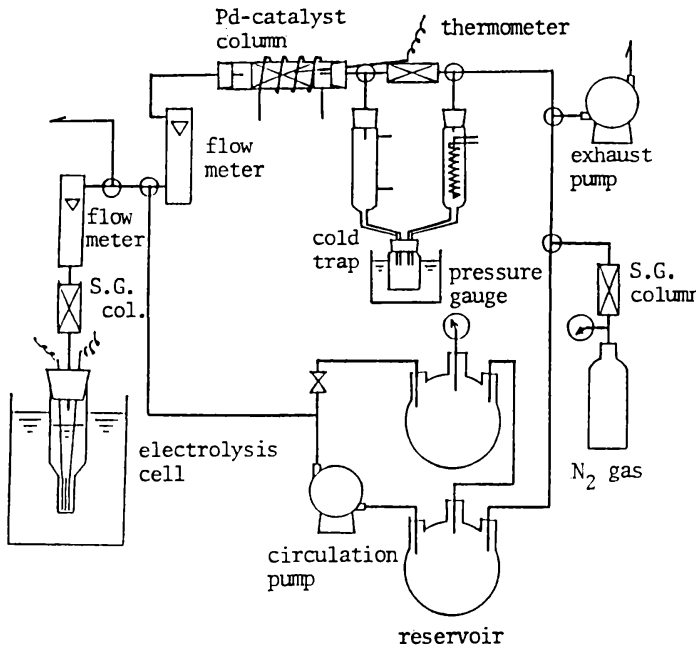

Fig. 3 Schematic diagram of apparatus designed for preparation of tritium-free water (S.G. : Silica Gel).
化し，水に戻すには，まず，爆発させないで連続的に酸 化できるシステムが必要である。

ここで，水素ガスの酸化および爆発の条件は

反応式 : $\mathrm{H}_{2}+1 / 2 \mathrm{O}_{2} \rightarrow \mathrm{H}_{2} \mathrm{O}$

反応熱 : $57.8 \Delta H_{0} \mathrm{kcal} / \mathrm{mol}$

爆発限界: $400^{\circ} \mathrm{C}, 4 \%(\mathrm{v} / \mathrm{v}) \mathrm{H}_{2} /$ 大気

である11)ので, 本システムでの酸化操作の条件を, 発生 した水素と酸素ガスを窒素気流中に誘導し,

水素ガスの濃度 : $4 \%(\mathrm{v} / \mathrm{v}) \mathrm{H}_{2} / \mathrm{N}_{2}$ 以下

酸化時の温度 : $200^{\circ} \mathrm{C}$ 以下

とした。一般に, 水素ガスの酸化触媒には金属 $\mathrm{Cu}, \mathrm{Pt}$ および Pd などが詳細に検討されている12 14). しかし， 安全に効率よく酸化するには，金属粉末より担持金属触 媒の使用が望ましいので，本研究では，これらの条件を 考慮し，Pdーアルミナ触媒を用い，Fig. 3 に示す総ガラ ス製の密閉系システムを作製した。

a) 窒素ガス循環系

システムの主要ラインには, 加工が容易なガラス管と シリコンチューブを用い, 内容積 $3 l$ の 4 頸ガラスフラ スコ 2 個をリザーバーとして使用した。また，循環ポン プにはベローズ式のェアーポンプ, 電解ガスおよび循環 ガスとの混合ガスの流量测定にはローターメーターを用 いた。

b) 触媒カラム

電解 $\mathrm{H}_{2}$ ガスを酸化し，水に戻すための触媒には，日

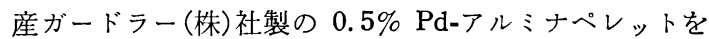
用い, 硬質ガラス管に充填した。ペレットおよびカラム への充埧条件 ${ }^{15)}$ は Table 2 に示すとおりである。

Table 2 Catalyst column conditions.

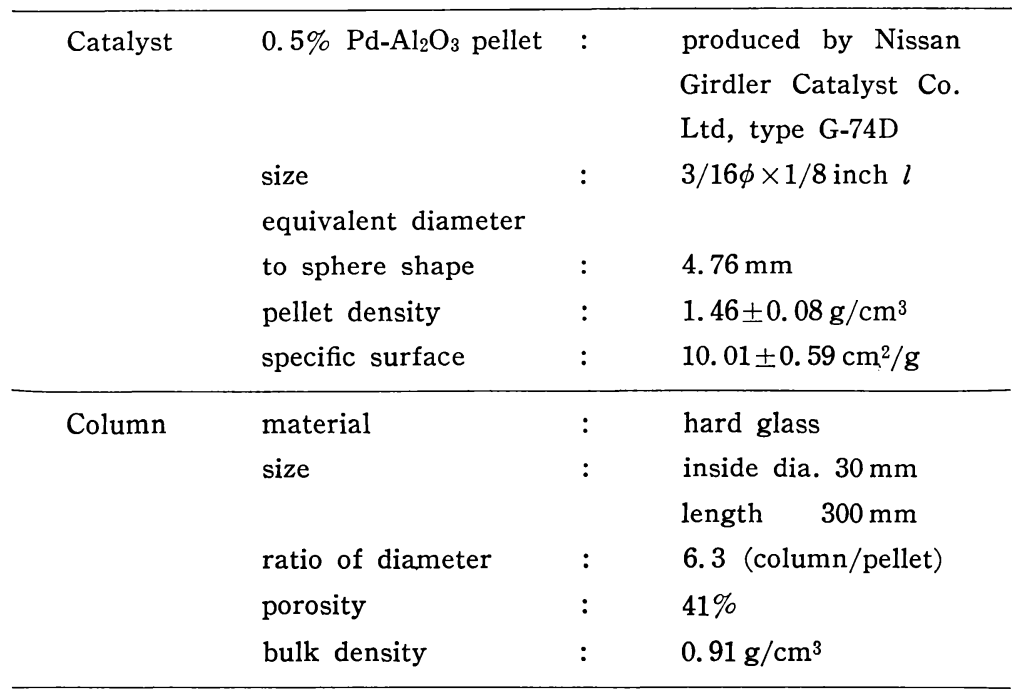


Table 3 Packed condition of catalyst pellet.

\begin{tabular}{cccc}
\hline \multirow{2}{*}{$\begin{array}{c}\text { Amounts of } \\
\text { catalyst }(\mathrm{g})\end{array}$} & \multicolumn{2}{c}{ Packed bed } & $\begin{array}{c}\text { Total surface area } \\
\text { of pellet }\left(\mathrm{cm}^{2}\right)\end{array}$ \\
\cline { 2 - 3 } 50 & 7.8 & flow time (s) & 503.5 \\
65 & 10.1 & 0.70 & 654.6 \\
85 & 13.2 & 0.92 & 856.0 \\
\hline
\end{tabular}

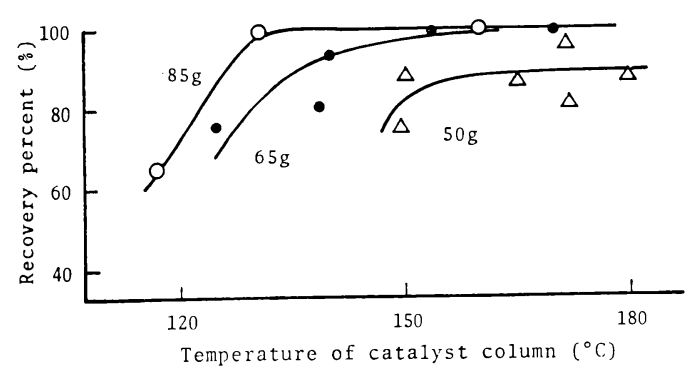

Fig. 4 Correlation between recovery percent of $\mathrm{H}_{2} \mathrm{O}$ and temperature of catalyst column.

c）回収トラップ

試料水の回収には, ドライアイスェタノール寒剤で冷 却した回収用トラップの前後にガラス製冷却管（球状冷 却器およびジムロート）を接続した。

\section{IV 水素の酸化と回収に関する予備実験}

Pd 触媒を用いると常温においても酸化反応が進むが， 発熱反応であるため, 電解ガス中の水素の酸化熱と循環 ガスの温度上昇およびカラム表面からの放熱効果と熱的 に平衡状態となる。酸化効率は, 水素ガスの発生速度, 混合ガスの流速, カラムへの触媒充塤量およびカラムの 温度などによって決まり，これらの因子は互いに関連し あっている。

このうち, 水素ガスの発生速度は電解電流値によって 決まり, 循環ガス中の水素濃度を上述のように $4 \%$ 以下 と条件つけると, キャリアーガスの流速も決まり, 酸化 効率を左右する因子をカラムへの触媒充媜量とカラム温 度にしぼることができる。したがって，まず，電解電流 值を $8 \mathrm{~A}$ および $12 \mathrm{~A}$ として, この二つの因子について の最適条件を実験的に求めた。

まず，原則として，触媒充填量を $50 \mathrm{~g}, 65 \mathrm{~g}$ および $85 \mathrm{~g}$ の 3 段階の条件とした。この条件で充填されたペレ ット層の比表面積, 充填長さおよびガスの通過速度は Table 3 に示すとおりである。結果として，これらの条 件で $\mathrm{N}_{2}$ ガスを循環させず，カラムを 1 回通過させる場 合の酸化効率とカラム温度との関係として表すと Fig. 4

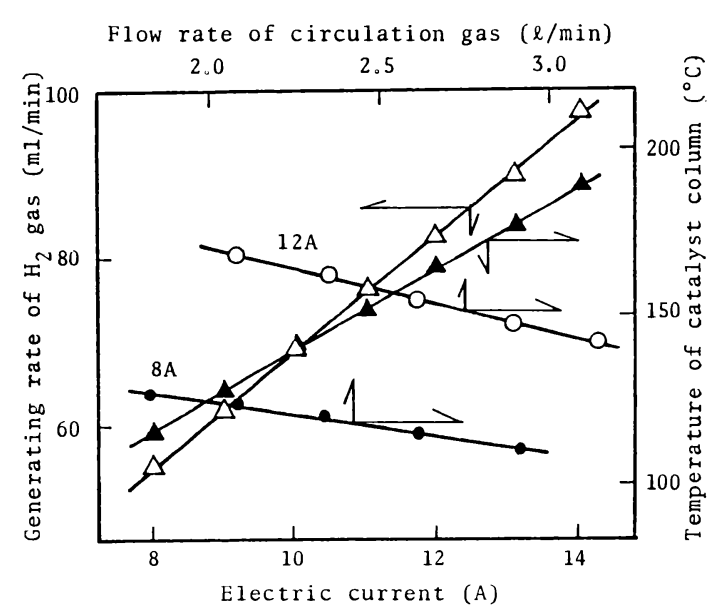

Fig. 5 Correlations between generating rate of $\mathrm{H}_{2}$, temperature of catalyst column, flow rate of carrier gas and electric current.

のようになる。つまり, カラム温度 $150^{\circ} \mathrm{C}$ でほぼ $100 \%$ の酸化効率が得られる。しかし, 充填量が少ない場合, たとえば，充填量を $50 \mathrm{~g}$ とすると，水素ガス濃度を増 やしてカラム温度を $150^{\circ} \mathrm{C}$ 以上に上げても酸化効率は約 80 90\% である。

また, 電流值 8〜14 A の範囲での水素発生率およびカ ラムの平衡温度との関係は Fig. 5 のとおりであり，電 流值 $12 \mathrm{~A}, \mathrm{~N}_{2}$ ガス循環速度 $2.4 \mathrm{l} / \mathrm{min}$ の条件では, 電 解ガス中の水素の燃焼による発熱によりカラム温度は約 $150^{\circ} \mathrm{C}$ となる。

以上の予備実験の結果と前項に示した条件を考慮し, 各操作での設定条件を

触媒カラム温度 : $150^{\circ} \mathrm{C}$

酸化回収効果: 約 $100 \%$

試料水の回収速度 : $40 \mathrm{ml} / 10 \mathrm{~h}$

回収試料水の

トリチウム濃度：試料原水の濃度の $10 \%$ 以下とし, 操作条件をつぎのように決定した。

[操作条件]

電解電流 : $12 \mathrm{~A}$ (電流密度 ; $190 \mathrm{~mA} / \mathrm{cm}^{2}$ ) 
恒温水槽温度 : $5^{\circ} \mathrm{C}$

$\mathrm{N}_{2}$ ガス循環量 : $2.4 \mathrm{l} / \mathrm{min}$

触媒充塤量 : $65 \mathrm{~g}$

\section{$\mathrm{V}$ 低トリチウム水の製造試験}

\section{1. 操作手順}

真空ポンプを用いて全システム内を減圧しながら触媒 カラムを約 $180^{\circ} \mathrm{C}$ に加熱し, 吸着水の焼き出しを約 30 分間行ら。つぎにキャリヤーガスとして $\mathrm{N}_{2}$ ガスを充埧 し，大気压とほぼ同じ圧力に調整し，循環ポンプにより $\mathrm{N}_{2}$ ガスを循環させ，電解ガスを混合させる。混合ガス を触媒カラム内に導き，ここで電解ガスを再結合させ， 水蒸気に戻し, 冷却トラップにおいて回収する。

以上, 一連の操作を 10 時間連続的に行い, $40 \mathrm{ml}$ の 試料を得た。必要に応じてこの操作を 3 回行い, 得られ た試料水 $120 \mathrm{ml}$ のちち, $100 \mathrm{ml}$ を用いて 2 段階目の処 理を行った。単操作のみで得た試料をStep-1，2段操作 を行って得た試料を Step-2 とした。

また，電解ガス発生用の試料原水には，大阪府泉南地 区に打いて採水販売されている深さ的 $1,000 \mathrm{~m}$ の地下水 (通称「和泉の水」, トリチウム濃度; 約 $0.37 \mathrm{~Bq} / l$ ) を 用いた。

\section{2. 製造実験の結果}

系統的な製造実験を数回繰り返し，電解および酸化回 収の工程について, 約 3 日で 2 段処理を行った試料水 $40 \mathrm{ml}$ を得ることが可能であり, 爆発その他のトラブル は生じなかった。

しかし, 得られた試料水のトリチウム濃度について, 使用した試料原水のトリチウム濃度がもともと天然の表 層水の平均的濃度の約 $1 / 2$ のレベルであり, また, 本電 解-酸化回収の操作によって得られた試料水のトリチウ ム濃度はさらに $1 / 10$ または $1 / 100$ 程度に低くなってい ると推察されるので, 実測による確認は困難である。統 計的誤差を上回る精度でその効果の有無を確認するに は，計算上では数カ月にもおよぶ長時間測定を㬰施する か, または, 得られた試料水を少なくとも 100 倍以上に 再濃縮して測定することが必要である。

\section{VI を と}

以上，得られた水が無トリチウム試料水であるか否か は未確認であるが, 電解法によって発生させた低濃度卜 リチウム水素ガスを連続的に, 安全に回収できる小規模 の水製造システムと操作条件が明らかになった。このシ ステムを採用することによって得られる利点として，以 下のことが上げられる。
（1）実験室規模に拈いて近くで入手できる試料水から 理論上では 2 段処理によって約 $1 / 100$ 以下のトリチ ウム濃度の試料を製造できると期待される

（2）比較的低温で酸化回収でき，爆発の危険が少ない

（3）二段階処理を行った試料水 $40 \mathrm{ml}$ を調整するのに 必要な時間は約 3 日である

な拝，触媒カラム内に吸着残留する水分をより完全に 除去すること，および外部からの污染を防止するため， 触媒カラムをステンレス製に，さらに Step-1 に掠ける 電解セルを $2 \sim 3$ 本直列に接続して増やし，処理時間を 短縮できるように変更したシステムに改造中である。

本研究を行うにあたり，Pd-アルミナペレットを提供 していただいた日産ガードラー(株)社，ならびに試料水 の測定にご指導，ご協力いただきました近畿大学原子力 研究所の河合廣元教授, 森嶋彌重教授および古賀妙子助 教授にお礼申し上げます。

\section{参考文献}

1) H. von Butler and W.F. LiBBY; J. Inorg. Nucl. Chem., 1, 75 (1955).

2) S. Kaufman and W.F. Libby; Phys. Rev., 93, 1337 (1954).

3）トリチウムの環境動態に関する総合研究班; 昭和 60 年文部省科学研究費補助金エネルギー特別研究 核融会報告書「環境トリチウムの測定とその動態 に関する研究」(1986).

4) H.C. Ostlund, M.O. Rinkel and C. Rooth : J. Geophys. Res., 74, 4535 (1969).

5) 斎藤正典, 古南英夫, 山田 治; 京都産業大学論 文集，第 7 巻, No. 4, 314 (1978).

6) 水口義則, 池辺幸正, 佐久間洋一, 天野 恕, 大 林治夫；保健物理， 24，31 (1987).

7）核融合特別研究総合総括班；昭和 62 年度文部省科 学研究費補助金研究成果報告書「トリチウム資料 集, 1988」, p.393 (1988).

8) 森島彌重, 古賀妙子, 丹羽健夫, 河合 廣; Radioisotopes, 36, 126 (1987).

9) 近藤裕一, 佐々木将博, 木村捷二郎：Radioisotopes, 33, 357 (1984).

10）木村捷二郎；未投稿.

11）化学ハンドブック編纂委員会；“化学ハンドブッ ク”, p. 340 (1978), オーム社, 東京.

12) K. Domen, S. Naito, M. Soma, T. Onishi and K. TAMARU; J. Chem. Soc., Faraday Trans. I., 78, 845 (1982).

13) M. Boudart, D.M. Collins, F.V. HANSON and W.E. SPICER; J. Vac. Sci. Technol., 14, 441 (1977).

14）大西孝治; “触媒”, p. 8 (1987)，大日本図書，東 京.

15）三輪茂雄；“粉粒体工学”, p.121（1972），朝倉書 店, 東京。 